\title{
Fish scenario in India with emphasis on Indian major
} carps

\begin{abstract}
India has a tremendous potential for the growth of fish based industries and presently one of the focus sector is fish production, marketing and consumption. The demand for fish is ever increasing because of its nutritive value being a rich source of protein. In India, the major carps, Catla (Catla catla), Rohu (Labeo rohita) and Mrigal (Cirrhinus mrigala) are the mainstay of freshwater aquaculture. The major carps are the most preferred farm fishes because of their fast growth and higher acceptability to consumers. Apart from this some of the Exotic major carps which are well adopted to Indian water are Cyprinus carpio (Common carp), Hypopthalmichthys molitrix (Silver Carp), Ctenopharyngodon idella (Grass Carp).
\end{abstract}

Keywords: Fish, Major carps, Catla, Rohu, Mrigal
Volume 3 Issue 6 - 2018

\author{
Basant Bais \\ Rajasthan University of Veterinary and Animal Sciences, India
}

Correspondence: Basant Bais, Department of Livestock Products Technology, College of Veterinary and Animal Sciences, Rajasthan University of Veterinary and Animal Sciences, Bikaner, Rajasthan, 33400I, India, Email basantbajs@gmail.com

Received: June 25, 2018| Published: November 16, 2018

\section{Introduction}

India is the second largest producer of fish next to China and Indonesia ranks third in aquaculture production. ${ }^{1}$ In India, this sector constitutes about $5 \%$ of the global fish production and $3 \%$ of the global fish trade. In the world, capture fisheries and aquaculture supplied about 158 million tons of fish in 2012, of which about 136.2 million tons was utilized as food. World per capita food fish supply increased from an average of $9.9 \mathrm{~kg}$ (live weight equivalent) in the 1960 s to $18.7 \mathrm{~kg}$ in 2011 and preliminary estimates for 2012 point to a further increase in fish consumption to $19.2 \mathrm{~kg}$. The per capita availability of fish in India has increased from $3 \mathrm{~kg}$ to $9 .{ }^{1}$ In India, the major carps, Catla (Catla catla), Rohu (Labeo rohita) and Mrigal (Cirrhinus mrigala) are the mainstay of freshwater aquaculture. The major carps are the most preferred farm fishes because of their fast growth and higher acceptability to consumers. ${ }^{2}$ Indian major carps are the most cultivable fish species in India contributing about $87 \%$ of the total freshwater aquaculture production of the country. ${ }^{3}$

India is one of the major fish producing countries in the world employing over seven million person in fishing and allied industries and contributing 60 crores annually to national income. ${ }^{4}$ India is one of the major fish producing countries in the world employing over seven million person in fishing and allied industries and contributing 60 crores annu $11 y$ to national income. ${ }^{4}$ Besides providing direct employment, this sector also supports canneries and processing establishments, gears and equipment manufacturers, boat yards, refrigeration and ice making plants and transport services in addition to those working in State Fisheries Department, Fisheries Corporation and other Government based fisheries institutions.

The shortage of human dietary protein can be provided by fish protein, particularly in developing countries, where protein shortage is serious. However, this goal may be difficult due to the high cost of good quality fish meals which costs about $40-60 \%$ of total operating costs in intensive aquaculture enterprises. ${ }^{5}$ Aquaculture can play an important role in meeting the future nutrition requirements of human population in terms of quality protein supply. Fish protein is easily digestible and has proved growth promoting value for human consumption. The fish protein comprises all the ten essential amino acids in desirable strength for body metabolism. Besides protein, fish flesh also offers minerals, vitamins and fat. Other qualities of fish flesh are: it is easier in cooking, palatable in taste, flavoured and quicker indigestion. Besides this, aquaculture can also play an important role in generating employment opportunities for the rural masses and largely the prevailing fish culture practices in our country is extensive and semi intensive type culture systems.

The demand for fish is ever increasing because of its nutritive value being a rich source of protein. The food insecurity problem in India has been alarming due to the rapid growth of population and the reduction of per capita land. The current scientific, economic, environmental and social trends are forcing farmer and policy makers to look for viable alternatives to fulfill the nutritional requirement for the growing population. Fish with an average of $18-21 \%$ protein can be best alternative in this context. A fisheries sector have been playing an important role in the national economy through improved food supply, employment and income, and contributes $1.5 \%$ to total GDP and $4.3 \%$ to the GDP from agriculture. ${ }^{6}$ Malnutrition is a worldwide problem for which the development of underexploited and unexploited fisheries resources offer a promising solution. Fish farming practices also hold promises for many small farmers and potential significant benefit for strengthening the rural economy. Another factor that adds to food security is the growth of fisheries sector. It is assumed that growth of fisheries sector during 2003-04 is about 6-7\% each year while that of agriculture sector between $2-3 \%{ }^{3}$

The natural genetic resources of Indian major carps come from the network of the Ganga river system, the Sindh and the Brahmaputra river systems in the north and the east-coast and west coast river systems flowing through in the south and central India respectively. The major carps of India fall under three genera, Catla, Labeo and Cirrhinus. Due to their fast growing nature and taste, Indian major carps enjoy a prime position in the Indian aquaculture scenario. These highly prized fishes though originally inhabitants of the Ganga river network in North India and the rivers of Pakistan, Bangladesh, Nepal and Burma, are also transplanted into other rivers in central as well as peninsular India. Besides this, these carps have been imported by many other countries such as Thailand, Vietnam, Laos. ${ }^{7}$ All Indian major carps naturally breed in rivers. They also breed in artificially created water bodies which are popularly known as "bundhs". However, Indian 
major carps though attain maturity in confined or stagnant (pond) waters, do not breed there and need inducement for spawning.

\section{Catla (Catla catla )}

In nature, the fish is found in lakes, ponds, rivers and reservoirs. It breeds only in running waters that is in rivers. It breeds in natural habitat during southwest monsoon and seeds are available from May to August and could be collected from the breeding grounds. Due to the success in induced breeding, this fish now can easily breeds in stagnant waters in fish farms.

It is a highly suitable fish for composite culture along with fishes that are column and bottom feeders. Catla breeds in flooded fields and can also breed by stimulating riverine condition in special ponds called dry bunds. The fingerlings feed on zooplankton and the adults are also consuming meroplanktons and vegetable matters. The mouth of Catla is wide upwardly directed. As the mouth is upwardly directed, it is surface feeder. Head is large and the body is comparatively very deep. The lower jaws are protruding. The colour of the body is black, fins and tails are dusky grey while belly is silvery white. In some species, fins are also dark black in colour. It attains maturity by the end of second year. Catla is the fastest growing, attaining a maximum size of $63 \mathrm{~kg}$. It contributes about $\mathrm{W}-60 \%$ to the total production from polyculture systems and is in great demand. However, the main disadvantage is its large head which reduces the portion of edible meat per unit weight. In well-managed farms it attains maturity in 18 months. The fecundity of female fish ranges from 24000 to 42 thousand eggs. The fries can be collected by the natural sources or induced breeding. Catla feeds mainly on Zooplankton at the upper zone of the water body.

Distribution of Catla catla, which starts from the Ganga river network in the north to the Krishna river down south of India, Pakistan, Bangladesh and Burma. It is also found in Nepal. The fingerlings of catla, introduced into the Cuddapah-Kurnool canal from river Godavari in 1909 found their way into river Penna and the connected waters in the Nellore district of the state of Andhra Pradesh. Catla fingerlings were also introduced in Cavery River during 1920s. Later the species was introduced into Periyar lake, Powai lake. Catla fingerlings have been also exported to Israel in 1954 and to Japan, and Mauritius in the 1960s. Catla has also been distributed to other countries like Zimbabwe, Israel, Bhutan, Philippines, Former USSR, Japan, Sri Lanka, Laos, Pakistan, Malaysia, Thailand, Vietnam and Mauritius.

\section{Rohu (Labeo rohita)}

Labeo Rohita is common in North India, Orissa and Bengal and is called Rohu but in Assam it is known as Rohiti. The body is elongated; dorsal profile is more convex, the colour of the body is bluish above and silver $y$ at the flanks. Eyes are reddish. In juvenile stage, it possesses dark band at the caudal peduncle. It has reddish tinge at the dorsal, pelvic, anal and caudal fins. The distinguishing feature is that the lips are fringed and the maxillary barbells are prominent.

As far as the distribution is concerned, it is available throughout nation in rivers and ponds. It is most delicious and, therefore, there is a great demand of this fish. It breeds in monsoon in rivers. Like other Cypriniformes, it does not breed in stagnant water. During breeding season the fish before breeding moves along with current of water, then take a turn and moves against the current of water and breeds in shallow water. It can successfully breed by induced methods. It grows fairly large in size but in comparison to Catla catla the growth is less. The fish becomes sexually mature in one year or so. The fecundity is $1.5-2.00$ (lac/g body weight). The fry and fingerlings could be obtained from the breeding grounds. Induced breeding in fish farms can successfully breed it. Adult as well as fingerlings feed on vegetable debris, Daphnia and decomposed water material. Other species of Labeo could also be cultured but from the economic point of view Labeo rohita and Labeo calbasu are profitable.

The medium-sized carp, Labeo fimbriatus, which is endemic to peninsular rivers, is a choice fish in the region due to its excellent flavour and meat quality. It is easy to induce this species to spawn. ${ }^{8}$ Because of its slow growth rate as compared to major carps, it is generally not included in polyculture systems. Day (1878 and 1889). reported that the species is distributed in freshwaters of Sindh and Punjab (Pakistan), through India, Assam, Bangladesh and Burma. He also stated that rohu is not found in South India. the occurrence of this species in many other places, viz., Sabarmati drainage, in the rivers Narmada, Tapti, Godavari, Mahanadi etc. though it is more common in plains of North India. It is also distributed in other neighbouring countries such as Bangladesh, Burma and Nepal.

\section{Mrigal (Cirrhinus mrigala)}

The common Indian species is Cirrhinus mrigala, but other species like C. cirrhosa, C. latia, C. reba and C. fulungee are also found in India.. The body of Cirrhinus mrigala is streamlined; the abdomen is round with deeply forked caudal fin. The snout is depressed, mouth is broad, transverse and obtusely round and the upper lip is entire. Barbels are two in number. The body colour is coopery, the flank is white with tinge of golden colour.

The colour of eye is golden. It attains an average length of about $40 \mathrm{~cm}$. and is found in rivers and lakes of northern India. It is also well acclimatized in South India for aquaculture. It breeds during monsoon months. It is most suited for induced breeding and now available throughout India. More than five inter-generic hybrid fries are available for culture. The fingerlings and adult feed more on animal protein. Both male and female mature at the age of two years. It is said that the induced breed fish mature only at the age of one year. C. mrigala breeds during monsoon. The fingerlings are available from natural grounds from July to November. The fish breeds naturally in rivers or induced riverine conditions due to the effect of pituitary hormone or other synthetic hormones.

As per Day (1878 \& 1889) Mrigal inhabits rivers and tanks (water bodies much larger than ponds) in Bengal (undivided which includes Bangladesh) Deccan, North-West provinces, Punjab, Sindh (Pakistan), Cutch (partly in Pakistan and partly in Gujarat, Rajasthan provinces of India) and Burma and in the major river systems of India, including river Godavari in the south.

\section{Exotic major carps which are well adopted to Indian water are as follows}

\section{Cyprinus carpio (Common carp)}

One of the world's important cultured fish. This fish was brought from China and was put in Ooty Lake. In 1947, it was introduced in Nainital and Kumanun hill. This was a cold- water fish. This fish is now well acclimatized in Indian waters and now found throughout the nation. Induced breeding in controlled conditions successfully breeds it. It has three main varieties viz.Cyprinus Carpio Specularis (mirror 
carp), Cyprinus Carpio Communis (scale carp), Cyprinus Carpio Nudus (leather carp).

\section{Hypopthalmichthys molitrix (Silver carp)}

It is also introduced in Indian waters from China. The fingerlings of this fish was brought from Japan in 1955 and cultured in fish farm at Cuttack. It is the fastest growing carp amongst indigenous and exotic fishes. The head is small and pointed, the lower lip is protruded interiorly but the upper lip is slightly bifurcated. The jaws are of equal length, the lower one is provided with tubercles, and upper jaw is slightly notched.The origin of dorsal fin is behind that of ventral fin. It is non-predatory fish like phytoplankton and zooplankton. It is the fastest growing exotic carp. It attains $2.0,3.5$ and $5 \mathrm{~kg}$ in first, second and third year respectively. The eyes are small. It feeds on protozoan and rotifers, vegetable are also consumed. It controls the algal bloom. It is surface feeder on account of mouth position. Barbels are absent The fecundity per kg body weight is approximately 0.8-1.0 (lakhs).

\section{Ctenopharyngodon idella (Grass carp)}

It is natural inhabitant of rivers of China. This fish was introduced in India first time in 1959 from Hong Kong and is now well acclimatized in India and distributed to various states in the country. Its growth is also fine and is a tasty fish and liked by Indians. The body is oblong and fairly compressed, head is small and pointed. Mouth is upturned. Breeding habit is similar to carps.

\section{Conclusion}

Thus the three Indian major carps, catla (Catla Catla), rohu (Labeo rohita) and (Cirrhinus mrigala) are the main components in composite fish farming in India Although some exotic major carps are also found and are well adopted to Indian water. Hence the carps appear to be of considerable importance to freshwater aquaculture in India.

\section{Acknowledgements}

None.

\section{Conflict of interest}

Author declares that there is no conflict of interest.

\section{References}

1. FAO. The State of World Aquaculture. Rome: FAO Fisheries Department; 2014. p. 3-27.
2. Saini VP, Ojha ML, Gupta MC, et al. Effect of dietary probiotic on growth performance and disease resistance in Labeo rohita (Ham.) fingerlings. International Journal of Fisheries and Aquatic Studies. 2014;1(6):07-11.

3. Ayyappan S, Jena JK. Grow-out production of Carps in India. Journal of Applied Aquaculture. 2003;13:251-282.

4. Gadage RS. Production and marketing of fish and fish preparations in India. Indian Journal of Agricultural Alarketing. 2005;19:61.

5. FAO. The State of World Aquaculture. Rome: FAO Fisheries Department; 1983. p. 144.

6. Sharma DK, Prakash B, Tyagi VP. Diversified products of fish: Helpful tools for fetching remunerative prices. Indian Journal of Agricultural Marketing. 2005;19:80.

7. Welcomme RL. International introductions of inland aquatic species. FAO Fish. 1988;294:318.

8. Devaraj KV, GY Keshavappa, JK Manissery. Growth of grass carp Ctenopharyngodon idella (val.) fed on two terrestrial fodder plants. Aquacult Fish Manage. 1986;17:123-128.

9. Ayyappan S, Diwan AD. Road map to increase fish production and productivity in India. Fishing Chimes. 2004;24(4):24-26.

10. Francis. The Fishes of India; being a natural history of the fishes known to inhabit the seas and fresh waters of India, Burma, and Ceylon. 1878.

11. Day Francis. The Fauna of British India, Including Ceylon and Burma. Fishes. 1889.

12. Day Francis. The Fishes of India; being a natural history of the fishes known to inhabit the seas and fresh waters of India, Burma, and Ceylon. 1878.

13. Singh S, Kingra HS, Singh S. Critical analysis of marketing of inland fish in Punjab. Indian Journal of Agricultural Marketing. 2005;19:69-70.

14. Somvanshi VS, Varghese S, Patil SM. Inland fish production in India: Prospective areas, conservation and management issues. Proceedings of DAEBRNS. 2007. p. 105.

15. Veerina SS, Nandeesha MC, Gopal Rao K. Status and technology of Indian major carp farming in Andhra Pradesh, India. Asian Fisheries Society Indian Branch, Mangalore Special Publication. 1973.9:52. 